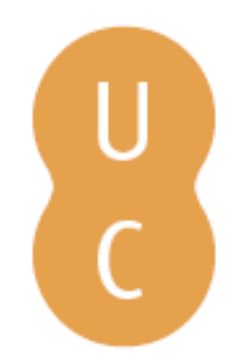

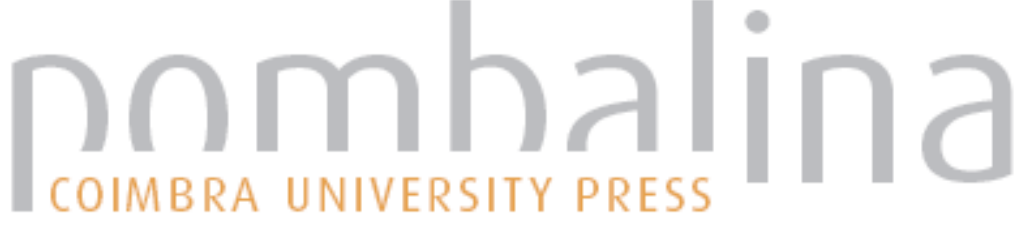

\section{Waves of information technology}
Autor(es):
Case, Donald O.

Publicado por: Imprensa da Universidade de Coimbra

URL persistente:

URI:http://hdl.handle.net/10316.2/31850

DOI:

DOI:http://dx.doi.org/10.14195/978-989-26-0319-3_3

Accessed : $\quad$ 26-Apr-2023 11:50:46

A navegação consulta e descarregamento dos títulos inseridos nas Bibliotecas Digitais UC Digitalis, UC Pombalina e UC Impactum, pressupõem a aceitação plena e sem reservas dos Termos e Condições de Uso destas Bibliotecas Digitais, disponíveis em https://digitalis.uc.pt/pt-pt/termos.

Conforme exposto nos referidos Termos e Condições de Uso, o descarregamento de títulos de acesso restrito requer uma licença válida de autorização devendo o utilizador aceder ao(s) documento(s) a partir de um endereço de IP da instituição detentora da supramencionada licença.

Ao utilizador é apenas permitido o descarregamento para uso pessoal, pelo que o emprego do(s) título(s) descarregado(s) para outro fim, designadamente comercial, carece de autorização do respetivo autor ou editor da obra.

Na medida em que todas as obras da UC Digitalis se encontram protegidas pelo Código do Direito de Autor e Direitos Conexos e demais legislação aplicável, toda a cópia, parcial ou total, deste documento, nos casos em que é legalmente admitida, deverá conter ou fazer-se acompanhar por este aviso. 
Maria Manuel Borges

Elias Sanz Casado

Coordenação

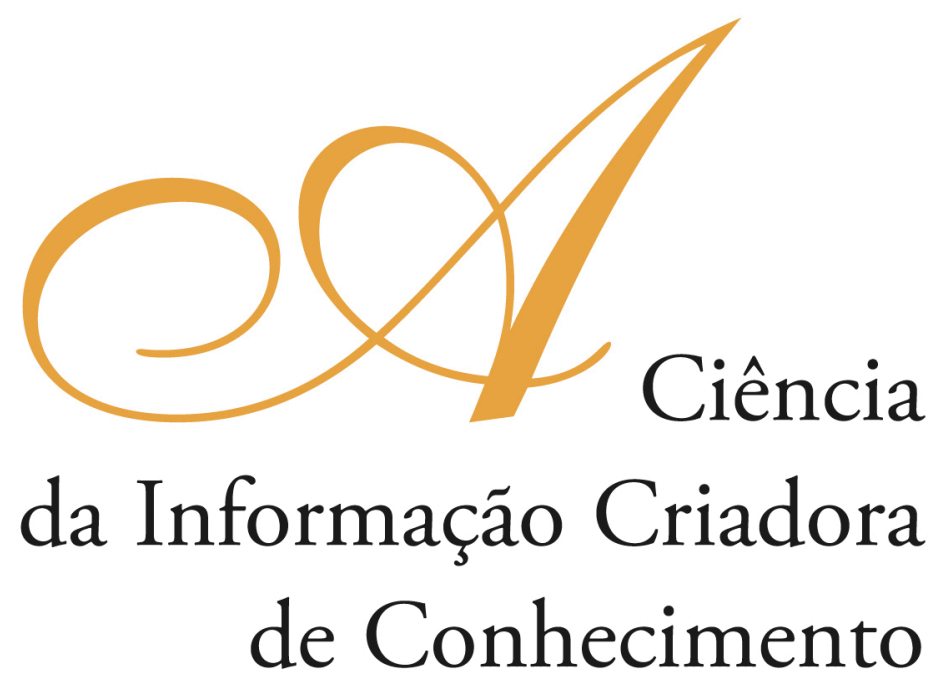

Vol. I

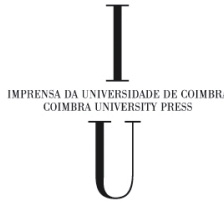

- COIMBRA 2009 


\title{
WAVES of Information TeChNOLOgY
}

\author{
Donald O. Case
}

University of Kentucky (EUA)

\begin{abstract}
This is a history of the various concepts and technologies of a public information utility. The first "wave" existed from about 1900 to 1945, and was centered on the idea of microfilm as an access mechanism to the world's information. The advocates included Paul Otlet (1934) of Belgium, Englishman H.G. Wells' vision of a "World Brain" (1938), and American Vanevar Bush and his "Memex" device (1945). The second wave consisted of the development of computers and their networks, which eventually gave rise to the videotex systems of the 1980s, and other pre-Web technologies. The third wave was the development of the World Wide Web in the 1990s, based on improved networks and software. In each of these waves, libraries and publishing were accorded some central role. Is there a fourth wave already: Web 2.0, the socalled "social web" of today? One could say that it is merely a minor extension of the $1990 \mathrm{~s}$ innovations, and be entirely correct. However, there is a sense in which this "social web" idea returns to earlier ideals of 100 years ago, rooted in notions regarding the evolution of society. Such ideas could be wrong, and even dangerous, however they seem to have powerful appeal to some members of society. But perhaps more of interest, what has happened to libraries, education and publishing in visions of the "social web"?
\end{abstract}

\section{Introduction}

I will share with you thoughts I have had in 25 years of writing about developments in information utilities for the general public (Case, 1985, 1986, 1990, 1994, 1997, 2007). Although they are absent from this paper, my presentation will include about 25 photographs and drawings to illustrate the history I describe below.

It is always tempting to think about human history as occurring in ages-e.g., the Renaissance, the Industrial Age-but those are simply convenient social constructions. It is the same with invention and technology: they do not proceed in neat phases or periods. However, for the purpose of this talk I will employ the following structure to discuss technical and social changes that have occurred in information science, as a way to consider where we are at present.

We can imagine "four waves" of development in providing information in formats other than the printed page. For the sake of convenience I will say that the first "wave" existed from about 1900 to about 1945, although it could be extended back to some indefinite date in the late $19^{\text {th }}$ century and extended into the future as well. This wave was largely the era of microfilm, a technology that continued to improve through the 1980s and is still with us, but increasingly antique and unpopular with users. For a period of about half a century microfilm was the basis for visions of the future of libraries.

The second wave is that of computer development, and the gradual connection of these devices to telephone and broadcasting networks. I will place the beginning of this second wave at 1946, rather than earlier, due mainly to the secrecy under which early computer developments were hidden from the public during World War Two. This encompasses two sets of developments: 
first, the growth in standalone computing technology through early mainframe computers to the advent of the personal computer; and second, the growth in network capabilities via conventional telephony and later specific computer protocols (Miller, 2009, calls this the "preWeb" period, from 1969 to 1992).

The third wave is the advent of World Wide Web, roughly 1991-2005. I place this period as beginning with the public release of the World Wide Web software by Tim Berners-Lee at the Conseil Européen pour la Recherche Nucléaire (CERN) in 1991 (Berners-Lee, 1999). The approach of using a graphical browser for searching and retrieval was truly a revolutionary break with earlier practices, as it opened up the Internet to a much wider range of users, and made the retrieval of images and sound much easier. The result was a flood of new applications, inventions and commerce.

The fourth wave - if it even exists - is the development of the "Social Web" starting about 2005 and continuing to today. In this stage we may have a return back to some of the goals of Paul Otlet a century before, while also raising some questions about the role of libraries and librarians in disseminating knowledge.

Please allow me to explain what I see during these four periods, and how they affect libraries and the information professions.

\section{Wave One: Microfilm, 1900 to 1945}

Until at least 1940, and perhaps as late as 1945, the idea of automated information retrieval was centered on the idea of microfilm as an access mechanism to the world's information. The historian Robert Williams (1998, p. 176) summarizes the activities of librarians and "documentalists" during this period as defined by an "orientation towards large-scale dissemination projects using microfilm."

Although applications of microphotography go back to at least 1860 (Meckler, 1982), it was not until about 1900 that it began to be used by wider audiences. In regards to libraries and information science, a key figure was the Belgian, Paul Otlet (Izquierdo Arroyo, 1995). A visionary author and entrepreneur, he could be considered the father of "documentation" or what is now more commonly called information science. He was the author of several books (e.g., Otlet, 1934) and essays (see Rayward, 1990) on how to organize and distribute the world's knowledge. Among his inventions was the faceted system of Universal Decimal Classification, an advanced system of organization still in use today. In addition to this invention, Otlet set up a system that used the postal mail to answer reference questions, a kind of "analog search engine." (Wright, 2007). Otlet was a strong advocate of microforms as the basis for the storage and retrieval of knowledge.

In 1906, Paul Otlet and Robert Goldschmidt (another Belgian) proposed that books be recorded on microfiche to save space and money (Rayward, 1990). Otlet wanted to create a World Center Library of Juridical, Social and Cultural Documentation, and he saw microfiche as a means to that goal. In a 1925 article, the two envisioned a great microform library from which each volume could printed on demand for patrons who would search the library remotely — with the help of librarian intermediaries (Rayward, 1990). In the same year Emanuel Goldberg demonstrated that one could put an entire book on a film the size of a large postal stamp (Buckland, 1992).

Another advocate of microforms for knowledge dissemination was the English writer H.G. Wells. In his 1938 book, Wells described "a common world brain" in the 
form of a comprehensive World Encyclopedia that would serve as a clearinghouse of information for all people on Earth (Wells, 1938; Campbell-Kelly \& Aspray, 1996; Case, 1997). Wells also corresponded with an American, Watson Davis, the founder of the American Documentation Institute (now the American Society for Information Science and Technology), about the potential of microfilm libraries.

A final figure whom I want to mention is Vannevar Bush. A prominent American scientist and engineer, Bush headed the United States Office of Scientific Research and Development during World War Two, coordinating scientific research projects related to the war effort. In this role he became a scientific advisor to U.S. President Franklin Roosevelt. Seeing the huge output of scientific material produced during this period, Bush became convinced that the existing system of dissemination needed to be improved. In 1945 he published an essay, "As We May Think" in a popular influential magazine, Atlantic Monthly. This article described a theoretical machine that he called a "Memex" for "Memory Extender." The goal of the Memex was to organize, retrieve and display information. Bush imagined this as a kind of desktop, within which information on microfilm could be projected for viewing-but not simply projected, also annotated, and linked to other information in storage (Bush, 1945, p. 103):

... a sort of mechanized private file and library ... in which an individual stores all his books, records, and communications ... It consists of a desk ... On the top are slanting translucent screens, on which material can be projected for convenient reading. There is a keyboard, and sets of buttons and levers ... if the user inserted 5000 pages of material a day it would take him hundreds of years to fill the repository, ... Most of the Memex contents are purchased on microfilm ...

But to Bush the key function of the Memex would be to create new links among different texts, including material entered by the user. For this reason, many credit him as the originator of the notion of hypertext (e.g., Nyce \& Kahn, 1989), although Rayward suggests this credit should go to Otlet (Rayward, 1992).

Librarians around the world adopted microforms as tools for information storage. For example, between 1927 and 1935, the Library of Congress of the United States microfilmed more than three million pages of books and manuscripts in the British Library. At their annual meeting in the United States in 1936, the American Library Association endorsed the use of microforms. By 1940 the $35 \mathrm{~mm}$ microfilm still in use today was perfected. A 1944 book (Rider, 1944) predicted that academic libraries would double in size every 16 years, and that a major way of saving space would be card-sized microforms (which later evolved into the microfiche with which we are familiar). By then many libraries were using microfilm to preserve local newspapers and other bulky material subject to deterioration. The further development of microfilm continued well into the 1980 's.

\section{Wave 2: Computers and Telephone Networks, 1946-1990}

Yet, by the 1940 s the eventual successor to microfilm storage had already appeared: the electronic computer. Beginning with devices designed in Germany and in the late 
1930s, computers slowly began to eclipse microfilm as a storage and access device. However, due to enforced secrecy during the World War these developments were not widely known until 1946, and were not exploited commercially until 1948 and later. As Weller (2008, p. 65) says "it was the impact of the Second World War and the Cold War that followed which precipitated the development of the first computers and early forms of what would become the World Wide Web." Williams (1998, p. 176) adds that during this period information scientists shifted away from broad plans for recording the world's literature and focused more on "the organization, control, and use of scientific documents."

As early as 1938 digital computers had been constructed by German engineer Konrad Zuse and by Bell Laboratories in the United States (Lubar, 1993). In 1940, British engineers constructed early versions of their "Bombes" for deciphering German military codes. Around the same time Zuse unveiled the Z3 computer, the first fully programmable computer. By the late 1950s over 80 manufacturers were selling so-called "mainframe" computers, largely to governments, universities and businesses (financial and insurance companies, and aircraft manufacturers were early users of these expensive devices). Computers continued to get smaller and cheaper (Campbell-Kelly \& Aspray, 1996), with implications that would not be appreciated until the 1980s.

Initially, direct-access computer memory (core or magnetic drum) was too precious to be used for large-scale storage of documents; large files were stored on magnetic tapes, which began to be used in computing in 1951 and continued to be common through the 1980s. Yet with new inventions, such as the direct-access disk memories of 1956, it became increasingly possible to store large amounts of material that could be directly accessed on mainframe computers. Although microfilm remained the preferred medium for archival storage, by the late 1970s computer output microfilm (COM) became a common way to offload computer files for long-term usage.

As the population of computers grew, mechanisms to connect them were developed, based initially on applications of existing telephone networks. The diffusion of packet-switching (1961), computer time-sharing (1963) and of devices such as the Interface Message Processor (1970) enabled remote usage of computers, as well as the file exchanges among them that were to become the basis for email systems. In 1982 BITNET and its European counterpart, EARN, became the first networks available to a broad academic user community. The development of the TCP/IP protocol in 1983 enabled a "network of networks" to evolve. By 1987 over 10,000 computers were linked, worldwide.

Libraries, especially in universities, directly benefited from these developments in a variety of ways. Computer-printed library catalogs appeared in the 1960 s, following the commercialization of high-speed computer printers in 1961. In 1963 projects at the Stanford Research Institute (SRI) led to such developments as the first online bibliographic search system, the first full-text search system, and the first long-distance, remote usage of such facilities. By 1968 Stanford University had developed the Stanford Public Information Retrieval System (SPIRES), which could support multiple users and files of customized information. The first system for shared cataloging (what was to become the OCLC Online Union Catalog) appeared in 1971, eventually including almost 1.5 billion records in 112 countries; the Bibiloteca Nacional de España, for 
example, is currently loading 3 million records into the WorldCat database (Case, 1997; OCLC, 2009).

In 1972 the first commercial database system, DIALOG, was introduced, soon to be followed by SDC ORBIT; among the early users of these systems were university libraries (Bourne and Hahn, 2003; García Moreno, 1994). During the 1970s large libraries began to acquire the teletype-like terminals needed to access such databases and print the results of searches. During the 1980s, a number of us were developing PC-based software to make it easier for "end-users" to effectively search these commercial databases, just as the database vendors and consumer information utilities were creating simplified versions of their systems for the general public (Case, 1986). This coincided with a parallel series of developments by organizations entirely outside the library or publishing world, such as national postal offices and telephone companies.

Besides spreading to the public via academic libraries, the benefits of computers and their networks began to appear in the home and public library. Beginning in 1972, early attempts by the British Post Office to make use of unused capacity in both phone lines and broadcasting spectrum, resulted in systems of home delivery for information, and later, the basis for business transactions. These forerunners of the WorldWide Web (Maurer, 2002), included the British Prestel, German Bildschirmtext and French Minitel (the latter used customized terminals, rather than a TV set). Maurer (2002, p. 798) describes how a British Telecom engineer observed that most families had a TV set and a telephone, and asked the obvious question: "Why not use the telephone to access services in a network of computers and use the TV set as display?" As Manuel Castells (1996, p. 341-342) says: "Television needed the computer to be free from the screen. But their coupling ... came after a long detour taken by computers in order to be able to talk to television only after learning to talk to each other." Combinations of the television with the telephone continued to be tried in until the early 1990s, e.g., in Portugal (Case \& Ferreira, 1990).

The Minitel, with an eventual seven million users, was the most successful of these attempts to provide images, information, email and transaction services to the public. Unlike most of the competing systems, Minitel was based on a customized terminal, rather than the television-a better approach, at least in the short-term. By the mid-1990s there were over 6.5 million Minitel terminals in place; one in every four French households had one, and one-third of all adults were using it.

However, all these systems ran into an unexpected development: computers were becoming so small and cheap that individuals could now afford them. Beginning in 1975 with crude "kits" that could be assembled by users, the microcomputer became increasingly powerful and inexpensive. The Altair 8800 of 1975 was the first "kit" computer based on the first semiconductor chips powerful enough to form the basis of a personal computer. Two years later the Apple II computer, requiring no assembly and simpler to operate, became widely popular. Between 1977 and 1981 other comparable machines were marketed, including the IBM PC. A new standard for usability was set with the introduction, in 1983, of the Apple Macintosh, with its graphical interface; this computer was simple enough to be used by children.

The personal computer, a general purpose device, replaced the single-purpose dumb terminals and ungainly television-keyboard-telephone combinations of videotex. Manuel Castells (1996, p. 345) discusses how videotex was not based on personal computing 
but on dumb terminals, "organized around a hierarchy of server networks, with little capacity for horizontal communication.” By 1980 many of us could afford a device that did the work previously accomplished by stand-alone machines: the terminal, the word-processor, the fax, the telephone, the videogame, etc.; when coupled to a printer, it allowed us to become publishers (Case, 1985).

Thus, with both large and small computers increasingly available for the storage of information, microfilm as a technology became increasingly outmoded. The parallel development of optical media like the CD-ROM during the 1980s (Lambert \& Ropiequet, 1986), further undermined microphotography for long-term storage of information. Although lacking the 100-year shelf-life of archival quality microfilm, optical media offered a cheap way to archive text, as well as images and sound.

In summary, Wave Two put in place all of the necessary infrastructure for an orderly and steady increase in capability, moving slowly towards giving more access to the ordinary citizen. However this situation changed radically with the introduction of the "disruptive innovation" of the World Wide Web-the Third Wave.

Wave Three: The Internet and World Wide Web, 1991 to 2005

The third wave was the development of the World Wide Web in the 1990s, based on existing telephone and computer networks. Again, we can see the beginnings of this wave in much earlier inventions. The design of the ARPANET, on which the early Internet was based, was discussed as early as 1964 . By 1969 the first two nodes (UCLA and Stanford University) were exchanging messages. A year later (1970) optical fiber was demonstrated as a medium to replace wire in sending signals. By 1973 the first Bulletin Board System (BBS) existed, a forerunner of the blogs and wikis of today. In 1979 and independent network, USENET, was open for public email, discussion groups and bulletin boards.

But it was not until developments in the early 1990s that the benefits of the Internet reached a larger population. This happened with the official transformation of networks like ARPANET and the European Academic and Research Network (EARN—which included representatives of both Portugal and España) into the current "Internet," and later the development of graphical browsers that made it easy for less-skilled users to retrieve images and text. In 1990 Tim Berners-Lee introduced a version of the World Wide Web (WWW) to scientists at CERN; this software used a hypertext markup language (HTML) to access both text and images (and, later, audio and video). CERN made the software public in 1991 - a year that also witnessed the release of the Wide Area Information Service (WAIS), and Gopher, a "point-and-click" distributed menu system and navigational aid. Wright (2007, p. 223-224) notes that "early Internet information-sharing applications like the Wide Area Information Server" and Gopher failed to achieve widespread use; however, the WWW is able to make use of these earlier protocols to accomplish what it does. The introduction of Mosaic in 1992 and Netscape Navigator in 1994 opened the Internet to any literate adult with access to a computer and a network. As Abbate (1999, p. 211) describes, it seemed like "an overnight sensation" to novices even though the underlying infrastructure had taken decades to achieve.

By 2006, over a billion people had used the Web at least once (Wright, 2006).

The vast majority of these people were first introduced to the WWW in one or both of two settings: school, or workplace. In education, libraries played a key role in introducing the wonders of the Web to young people at all levels of education. 
At the university level, in particular, Internet offered access to an increasing amount of the world's scholarly and scientific information, as well as all the trappings of popular culture. Universities also became involved in actually publishing, as well as disseminating, scientific and scholarly literature (Lustria \& Case, 2005; Marcum, 2006). In those nations wealthy enough to afford public libraries, the WWW is available to the entire population. In almost every country Internet cafes provide public access for a reasonable price.

Why isn't Wave Three also considered the Wave of the Computer," like Wave Two? Because with the integration of chips in all devices, coupled with advances in mobile networks, distributed intelligence and the development of "cloud computing," it is not so obvious that each individual will need a powerful, standalone computing device as was true in the past. The information and processing will increasingly be distributed across a network of other devices across the world, and few of these will be "computers" as we now know them.

\section{Wave Four: The Social Web (2.0), 2005 to the Present}

Although a "Web 2.0" was hinted at as early as 1999 (DiNucci, 1999) and first appeared in a title in 2002 (McCormack, 2002) it was not until about 2005 that we begin to see Web 2.0 and Library 2.0 become popular phrases, first on blogs and then in subsequent publications (e.g., Miller, 2005; Grossman, 2006; O’Reilly, 2006).

According to the software guru Tim O'Reilly (2006), Web 2.0 would "Build applications that harness network effects to get better the more people use them . . . harnessing collective intelligence.» Sometimes called "The Social Web," Web 2.0 is supposed to be built upon applications that connect people directly to one another, in a "many-to-many," collaborative network (Blattmann \& Corrêa da Silva, 2007). These applications include blogs, wikis, podcasts, social tagging, media sharing sites such as YouTube and social networking sites like FaceBook (Cabezas Mardones, 2008). The vision is of masses of users creating content for other masses of users while they construct their own communities. There is even talk of a "Web 3.0" in the future, a so-called "intelligent web" that would better understand human language and automatically find or create metadata for digital objects.

Web 2.0 features some applications that are genuinely new and unexpected, as well as extensions of inventions that go back to the early days of electronic commerce (e.g., bookseller Amazon's encouragement of user comments). These applications have been extremely popular, especially among the youngest users of the Internet (Gibbons, 2007). As Weller (2008, p. 65) notes, "Social networking sites and web 2.0 technologies have allowed personal communication and information sharing on a hitherto unseen scale." To take just one example, by 2009 Facebook had more than 300 million users in 180 countries worldwide; these users send more than 40 million updates every day. Grossman (2006) emphasizes the newness and popularity of these new applications when he says:

The new Web is a very different thing. It's a tool for bringing together the small contributions of millions of people and making them matter. Silicon Valley 
consultants call it Web 2.0, as if it were a new version of some old software. But it's really a revolution.

In the case of the library, the goal is thought to be an increased flow of information from the library patron back to the library, as well as facilitating information dissemination from the library to the user, and from library to library, and user to user. It is thought that this will not only create new, useful content, but also create communities of practice and interest-increasing social capital (Lin, 2002). In another way it also opens access to the "Long Tail" (Anderson, 2006) of less popular works and gray literature that have been underappreciated in the past.

The online public access catalog (OPAC) is one vehicle for providing some of these features. E.g., allowing users to provide their own "tags" to supplement the library-supplied descriptors for works (Margaix Arnal, 2007). According to Paul Miller (2005), libraries need to either adopt these tools or face threatening competition from commercial entities:

Libraries were once the guardians of knowledge, and the point at which those seeking existing knowledge would engage with it. With the rise of Google, Amazon, Wikipedia and more, there is an oft-stated fear that many users, much of the time, will bypass processes and institutions that they perceive to be slow, unresponsive, unappealing and irrelevant in favour of a more direct approach to services offered by others that just might be 'good enough' for what they need to do. Libraries should be seizing every opportunity to challenge these perceptions, and to push their genuinely valuable content, services and expertise out to places where people might stand to benefit from them; places where a user would rarely consider drawing upon a library for support.

In an important sense the Web 2.0 emphasis on social goals brings us back to the objectives of Otlet, Wells and others, who wanted to disseminate knowledge in a way that did not require the receiver to have a university education. The "World Brain" of English author H.G. Wells (1938) was an evolving encyclopedia that would enable all the world's people to become better informed. Wright (2006) calls Otlet's work "the web that wasn't," simply due to the limitations of the technology of his day. Otlet, in fact, suggested something very much like today's Web when he described a desk with a screen and telephone, having remote access (via telephone, telex, radio and television signals) to vast collections of catalogs, bibliographies and indices.

But is Web 2.0 really a new Wave? And is it a good idea?

Yet Otlet differed with today's Web environment on a key point: the search and retrieval would be carried out by experts, not untrained individual users (Rayward, 1994). To Otlet, libraries and librarians were still the guardians of knowledge; he recognized that technology itself was not the sole determinant of what we should do as professionals and scholars. To allow complete user access to (much less, control of) content and its organization would imply that users could reliably do a competent job of that; Otlet would not have approved. According to Rayward (1994), Otlet believed that the user must adapt to the systems not the systems to the user; his view of knowledge was an authoritarian one, in which experts identified "facts" and screened out all else. 
In an important way the idea of a social web undermines the work that librarians have done for centuries: supporting and disseminating the work of scholars and scientists. Thus, the social web moves away from the goals of Otlet and Wells and others who, a century before, envisioned a comprehensive repository of vetted knowledge - information we could trust as having been carefully constructed and criticized before publication. Wright (2006) suggests that Web 2.0 advocates are confused partly because they see it as an extension of publishing; however, the web is not primarily a place to publish, that is, a kind of library, but rather it is more of a place to "talk" - a return to the oral tradition of ancient times in which everyone has an opinion to report, but cannot take the time to document, and provide evidence for, what they say.

A related criticism of Web 2.0 is that it is yet another case of technological determinism: that new developments in computing, and their advocates, are driving libraries to implement applications-whether or not they make sense. Some librarians feel that to even question whether a certain innovation really helps users is to risk being labeled a "Luddite," unthinkingly opposed to all technology.

Is Web 2.0 (or Library 2.0) really a new "wave"? Some commentators say that "Web 2.0" does not represent a new version of the World Wide Web at all, The underlying, technical protocols (such as HTTP) have not been replaced; rather, there are simply more, and in some cases newer, applications of the technology. And even such hallmarks as user-generated content have been around since the mid-1990s, e.g., some online vendors have encouraged users to write reviews of products like books, music and software applications (Scholz, 2008). A frequent blogger on the topic is much more blunt (Farkas, 2006):

Library 2.0 and Web 2.0 don't exist. Web 2.0 is hype. Library 2.0 is just a bunch of very good ideas that have been squished into a box with a trendy label slapped on it ... we're spending way too much time defining something that has existed in one form or another for quite a long time and will exist when the meme has ended.

So it is not surprising that there is a fair amount of skepticism about the ultimate value of Web 2.0 applications in general, not just as they appear in libraries (Grossman, 2006):

Web 2.0 harnesses the stupidity of crowds as well as its wisdom

... But that's what makes all this interesting. Web 2.0 is a massive social experiment, and like any experiment worth trying, it could fail.

For such reasons there is concern within libraries that users cannot always be trusted to accurately and responsibly tag library documents. Critics say that Web 2.0 promotes amateurism, undermining expertise by allowing anyone to publish their own opinions about any topic regardless of their knowledge or biases (Petersen, 2008).

There is also concern that library users will not actually adopt these new library features even if they are implemented. And, for whatever reason, they are not yet widely diffused across all libraries. For example, although $95 \%$ of 64 major academic libraries surveyed by the U.S. Association of Research Libraries (Bejune \& Ronan, 2008) 
say they are using social networking applications, it is primarily instant messaging, Really Simple Syndication (RSS), wikis and blogs that have been implemented; just $55 \%$ had used tagging. Further, an examination of 81 less-elite academic libraries in the United States (Xu, Ouyang \& Chu, 2009) found only $42 \%$ to be using Web 2.0 applications, the most common being instant messaging, blogs and RSS. The most heavily-advertised applications - tagging, wikis, social networking and podcasts-were used by less than $7 \%$ of these academic libraries. While part of the disagreement between these two studies lies in their distinct methodologies, it is clear that they indicate both a diversity of approaches and a lack of certainty about the ultimate usefulness of these applications - most of which are easy to implement but difficult to evaluate. And it is only through rigorous evaluation that we will only know that these innovations are really useful.

Even deeper criticisms of Web 2.0 question its underlying assumptions about profit motives and privacy. In a preface to a special issue on this topic, Zimmer (2008) warns that

Web 2.0 also embodies a set of unintended consequences, including the increased flow of personal information across networks, the diffusion of one's identity across fractured spaces, the emergence of powerful tools for peer surveillance, the exploitation of free labor for commercial gain, and the fear of increased corporatization of online social and collaborative spaces and outputs.

Is the enthusiasm behind the social web, then, just more business promotion or utopian rhetoric? I do not think so. However, I also doubt that it is truly a "Fourth Wave," even if we consider the added potential of the so-called "Web 3.0" developments. None of the additional capabilities of the social web or mobile computing appear to be as disruptive as the invention of the digital computer, or the confluence of technologies that created the World Wide Web.

However, history teaches us that it is extremely difficult to make accurate predictions about the effects of technologies. It is too early to say whether we are now witnessing another revolution in libraries - that of Library 2.0-or rather a simple evolution of earlier technologies and applications. So, have there been four waves, or merely three? And when will the next wave appear? We know it is coming, we just do not know when it will arrive until it sweeps over us.

\section{References}

Anderson, C. (2006). The long tail: Why the future of business is selling less of more. New York: Hyperion. Bejune, M. \& Ronan, J. (2008). SPEC Kit 304. Social Software in Libraries. Washington, DC: Association of Research Libraries.

Berners-Lee, T. (1999). Weaving the web. San Francisco: HarperCollins.

Blattmann, U. \& Corrêa da Silva, F.C. (2007). Colaboração e interação na Web 2.0 e Biblioteca 2.0 Revista ACB 12(2), 191-215.

Bourne, C.P. \& Hahn, T.B. (2003). A history of online information services: 1963-1976. Cambridge, MA: MIT Press. 
Buckland, M.K. (1992). Emanuel Goldberg, electronic document retrieval, and Vannevar Bush's Memex. Journal of the American Society for Information Science 43, 284-94.

Bush, V. (1945). As we may think, The Atlantic Monthly, 176(1), 101-108.

Campbell-Kelly, M. \& Aspray, W. (1996). Computer: A history of the information machine. New York: Basic Books.

Cabezas Mardones, C. (2008). Leer y escribir en la web social: uso de blogs, wikis y multimedia compartida en educación. Serie Bibliotecología y Gestión de información (35), 1-16.

Case, D.O. (1985). The personal computer: missing link to the electronic journal. J. American Society for Information Science, 36(5), 309-313.

Case, D.O. (1986). Three paths to end-user searching. Journal of Educational Media \& Library Sciences, 23(2), 103-112.

Case, D.O. \& Ferreira, J.H. (1990). Telecommunications and information technologies in Portugal: Development and prospects. Telecommunications Policy, 14 (4), 290-302.

Case, D.O. (1994). The social shaping of videotex: How information services for the public have evolved. Journal of the American Society for Information Science, 45 (7), 483-497.

Case, D.O. (1997). What the OCLC Online Union Catalog means to me. Journal of Library Administration, 25 (2/3), 5-6.

Case, D.O. (2007). Looking for information: A survey of research on information seeking, needs, and behavior. Second edition. New York: Academic Press.

Castells, Manuel (1996). The end of the millennium, the information age: Economy, society and culture, v. 1. Oxford: Blackwell.

DiNucci, D. (1999). Fragmented future. Print, 53 (4), 32.

Farkas, Meredith. (2006). Label 2.0. Retrieved August 27, 2009, from:http://meredith.wolfwater. com/wordpress/2006/01/06/label-20/

García Moreno, M.A. (1994). Nacimiento y desarrollo de la teledocumentacîon en España: 1973-1979. Documentacîon de las Ciencias de la Informacîon, 17, 39-66.

Gibbons, Susan. (2007). The academic library and the net gen student: making the connections. Chicago: American Library Association.

Grossman, Lev. (2006). Person of the year: You. Time, 168(26). Retrieved August 26, 2009, from:http://www.time.com/time/covers/0,16641,20061225,00.html.

Izquierdo Arroyo, J.M. (1995). La organizacion documental del conocimiento. Madrid: Tecnidoc.

Lambert, Steven \& Ropiequet, Suzanne. (Eds.) (1986). CD ROM: The new papyrus: The current and future state of the art. Redmond, WA: Microsoft press.

Lin, N. (2002). Social capital: A theory of social structure and action. Cambridge, Cambridge University Press.

Lubar, Steven. (1993). InfoCulture: The Smithsonian book of information age inventions. New York: Houghton Mifflin.

Lustria, M.L.A. \& Case, D. (2005). The SPARC Initiative: A survey of participants and features analysis of their journals. Journal of Academic Librarianship, 31, 236-246.

Marcum, D., \& George, G. (2006). Digital library development: The view from Kanazawa. Englewood, CO: Libraries Unlimited.

Margaix Arnal, D. (2007). El OPAC Social, el catálogo en la Biblioteca 2.0. Aplicación y posibilidades en las bibliotecas universitarias . P. 199-205 in Proceedings 10as Jornadas Españolas de Documentación, Santiago de Compostela, España.

Maurer, H. (2001). Videotex. In R. Rojas (Ed.) Encyclopedia of computers and computer history, Vol. Two (pp. 798-799). Chicago: Fitzroy Dearborn Publishers. 
McCormack, D. (2002). Web 2.0: 2003-'08 AC (After Crash) The resurgence of the Internet and ecommerce. Boston, MA: Aspatore Books.

Meckler, A.M. (1982). Micropublishing. Westport, CT: Greenwood.

Miller, J.B. (2009). Internet technologies and information services. Westport, CT: Libraries Unlimited.

Miller, P. (2005). Web 2.0: Building the new library. Ariadne, 45 (October). Retrieved August 21, 2009, from: http://www.ariadne.ac.uk/issue 45/miller/

Nyce, J.M. \& Kahn, P. (1989). Innovation, pragmaticism, and technological continuity: Vannevar Bush's Memex, Journal American Society Information Science, 40(3), 214-220.

OCLC (2009). WorldCat: Window to the world's libraries. Retrieved Sept. 15, 2009, from: http://www.oclc.org/worldcat/default.htm

O'Reilly, T. (2006). Web 2.0 compact definition: Trying again. Retrieved August 21, 2009, from: http://radar.oreilly.com/archives/2006/12/web_20_compact.html.

Otlet, P. (1934). Traité de documentation. Le livre sur le livre: Théorie et pratique (1989 reprint). Liège : Centre de Lecture publique de la Communauté française .

Petersen, S.M. (2008). Loser generated content: From participation to exploitation. First Monday, 13(3), 2008. Retrieved August 29, 2009, from: http://www.uic.edu/htbin/cgiwrap/bin/ojs/ index.php/fm/issue/view/263/showToc

Rayward, W.B. (Trans and Ed.) (1990). The international organization and dissemination of knowledge: Selected essays of Paul Otlet. Amsterdam: Elsevier.

Rayward, W.B. (1994). Visions of Xanadu: Paul Otlet (1868-1944) and hypertext. Journal of the American Society of Information Science, 45, 235-250.

Rider, F. (1944). The scholar and the future of the research library. New York: Hadham Press.

Scholz, T. (2008). Market ideology and the myths of Web 2.0. First Monday, 13(3), 2008. Retrieved August 21, 2009, from: http://www.uic.edu/htbin/cgiwrap/bin/ojs/index.php/ $\mathrm{fm} /$ issue/view/263/showToc

Weller, T. (2008). Information history: An introduction: Exploring an emergent field. Oxford, UK: Chandos Publishing.

Wells, H.G. (1938). World Brain. Garden City, NY: Doubleday.

Williams, R. (1998). The documentation and special libraries movement in the United States, 1910-1960. In Hahn, T. \& Buckland, M. (Eds.) Historical studies in information science (pp. 171-179). Medford, NJ: Information Today, Inc.

Wright, A. (2007). Glut: Mastering information through the ages. Washington, DC: Joseph Henry Press.

Xu, C., Ouyang, F. \& Chu, H. (2009). The academic library meets Web 2.0: Applications and implications. Journal of Academic Librarianship, 35(4), 324-331.

Zimmer, M. (2008). Preface: Critical perspectives on Web 2.0. First Monday, 13(3), 2008. Retrieved August 21, 2009, from: http://www.uic.edu/htbin/cgiwrap/bin/ojs/index.php/ $\mathrm{fm} /$ issue/view/263/showToc 